\title{
CHEK1 wt Allele
}

National Cancer Institute

\section{Source}

National Cancer Institute. CHEK1 wt Allele. NCI Thesaurus. Code C51196.

Human CHEK1 wild-type allele is located within 11q24-q24 and is approximately 29 kb in length. This allele, which encodes serine/threonine-protein kinase Chk1 protein, plays a role in the induction of cell cycle arrest at the G2/M checkpoint in response to either DNA damage or the presence of unreplicated DNA. 